\title{
Discussion on Moderate Size of Foreign Exchange Reserves in Our Country
}

\author{
Shaokang $\mathrm{Ma}^{1,}$,, Yixin $\mathrm{Liu}^{2, \mathrm{~b}}$ \\ 1School of Finance and Trade, Zhuhai College of Jilin University, Zhuhai 510941, China; \\ ${ }^{2}$ School of Finance, Jilin University of Finance and Economics, Changchun 130117, China. \\ a330209592@qq.com, b1320308891@qq.com
}

\begin{abstract}
Moderate size of foreign exchange reserves is the key to quantity management. During 40 years of reform and opening-up policy, the foreign exchange reserves in our country increase by more than 3000 times. At present, it is 3 trillion dollars and accounts for $28 \%$ of foreign exchange reserves of the world, thus ranking first for a long time. Then, which is the moderate size for foreign exchange reserves in our country? How to scientifically determine moderate size of reserves? These are important and practical problems that we are faced with. Research in the Paper focuses on moderate foreign exchange reserves in our country and relevant economic theoretical models are used to consider variable factors which mainly influence foreign exchange reserves according to practical situation in our country. Therefore, we will know basic data about moderate foreign exchange reserves in our country to provide basis and reference for quantity management of foreign exchange reserves in our country.
\end{abstract}

Keywords: Foreign exchange reserves, moderate size and quantity management.

\section{Introduction}

There are great changes in rise and fall of foreign exchange reserves in our country: 840 million dollars in 1979, 165.574 billion dollars in 2000, 3843.018 billion dollars in 2014 and 3110.6 billion dollars in May 2018. On one hand, it is the result of macro-economic operation in our country. On the other hand, it is the reflection of loss of control in quantity management of foreign exchange reserves in our country. Then, which is the moderate size of foreign exchange reserves in our country?

\section{Demands of Foreign Exchange Reserves at A Single Level}

\subsection{Demands of Foreign Exchange Reserves in Prudent Motivation}

In the middle of last century, Tiffin, an American economist, proposed proportion analysis model which is the first standard accepted by International Monetary Fund (IMF). He thought, foreign exchange reserves of a country shall be equivalent to input amount of three to four months, namely about $30 \%$ of input amount of the whole year. The moderate and theoretical amount of foreign exchange reserves can be calculated according to $30 \%$ of import amount in the current year from 2000 to 2016. The result is that, from 2000 to 2004, the size of foreign exchange reserves and import amount increased steadily and the increase level was close to each other. Therefore, the actual amount of foreign exchange reserves is always 3 to 4 times of moderate and theoretical amount of foreign exchange reserves. In 2005, People's Bank of China announced to carry out reform in exchange rate mechanism, which started marketization of RMB exchange rate. Later on, the size of foreign exchange reserves in our country increased rapidly and it was up to 6.6 times of moderate and theoretical amount of reserves at the greatest extent. In the second half of 2014, the size of foreign exchange reserves in our country showed the trend of month-on-month decrease for the first time. However, due to decrease of import amount in the same period, the actual foreign exchange reserves were still more than 6 times of moderate and theoretical amount of foreign exchange reserves at the end of 2016. 
Table 1. Demands of foreign exchange reserves in prudent motivation

\begin{tabular}{c|c|c|c}
\hline year & Imports & $30 \%$ of Imports & Foreign Exchange Reserves (R) \\
\hline 2000 & 2250.9 & 675.27 & 1655.74 \\
\hline 2001 & 2435.5 & 730.65 & 2121.65 \\
\hline 2002 & 2951.7 & 885.51 & 2864.07 \\
\hline 2003 & 4127.6 & 1238.28 & 4032.51 \\
\hline 2004 & 5612.3 & 1683.69 & 6099.32 \\
\hline 2005 & 6599.5 & 1979.85 & 8188.72 \\
\hline 2006 & 7914.6 & 2374.38 & 10663.44 \\
\hline 2007 & 9561.2 & 2868.36 & 15282.49 \\
\hline 2008 & 11325.7 & 3397.71 & 23991.52 \\
\hline 2009 & 10059.2 & 3017.76 & 28473.38 \\
\hline 2010 & 13962.4 & 4188.72 & 31811.48 \\
\hline 2011 & 17434.8 & 5230.44 & 33115.89 \\
\hline 2012 & 18184.1 & 5455.23 & 38213.15 \\
\hline 2013 & 19499.9 & 5849.97 & 38430.18 \\
\hline 2014 & 19592.3 & 5877.69 & 33303.62 \\
\hline 2015 & 16819.5 & 5045.85 & \\
\hline 2016 & 15874.8 & 4762.44 & \\
\hline
\end{tabular}

Unit: hundred million US dollars

Source of data: [1] Information on: http: //www. Stats. Gov. Cn, [2] Information on: http: //www. Safe. Gov. Cn

Table 2. Demands of foreign exchange reserves in preventive motivation (I)

\begin{tabular}{c|c|c|c}
\hline year & $\begin{array}{c}\text { short-term external } \\
\text { debt(SD) }\end{array}$ & $\begin{array}{c}\text { 3 times short-term external } \\
\text { debt }\end{array}$ & $\begin{array}{c}\text { Foreign Exchange } \\
\text { Reserves(R) }\end{array}$ \\
\hline 2000 & 130.8 & 392.4 & 1655.74 \\
\hline 2001 & 837.7 & 2513.1 & 2121.65 \\
\hline 2002 & 870.8 & 2612.4 & 4032.51 \\
\hline 2003 & 1027.7 & 3083.1 & 6099.32 \\
\hline 2004 & 1387.1 & 4161.3 & 8188.72 \\
\hline 2005 & 1716.4 & 5149.2 & 10663.44 \\
\hline 2006 & 1992.3 & 5976.9 & 15282.49 \\
\hline 2007 & 2356.8 & 7070.4 & 23991.52 \\
\hline 2008 & 2262.8 & 6788.4 & 28473.38 \\
\hline 2009 & 2592.6 & 7777.8 & 31811.48 \\
\hline 2010 & 3757 & 11271 & 33115.89 \\
\hline 2011 & 5009 & 15027 & 38213.15 \\
\hline 2012 & 5409.3 & 16227.9 & 38430.18 \\
\hline 2013 & 6766.3 & 20298.9 & 33303.62 \\
\hline 2014 & 6211 & 18633 & 30105.17 \\
\hline 2015 & 4791.1 & 14811 & 17243.1 \\
\hline 2016 & 5747.7 & & \\
\hline
\end{tabular}

Unit: hundred million US dollars

Source of data: [1] Information on: http: // www. Stats. Gov. Cn, [2] Information on: http: //www. Safe. Gov. Cn

\subsection{Demands of Foreign Exchange Reserves in Preventive Motivation}

(I) Alan Greenspan, the 13th President of Federal Reserve Board (1987 to 20006), proposed that the demands of capital flow shall be considered for the size of foreign exchange reserves. Therefore, the proportion between foreign exchange reserves and balance of short-term foreign debt is deemed as an important symbol of a country's debt paying ability and the international warning line is $100 \%$. The moderate and theoretical amount of foreign exchange reserves (debt crisis, inflow of hot money and other factors in economic globalization are taken into consideration) will be calculated according 
to 3 times of the balance of short-term foreign debt from 2000 to 2016. From 2001, in statistic methods and dimensions about the balance of foreign debt, the balance of external financing for trade accounts in three months is added and therefore the proportion of the balance of short-term foreign debt in total balance increased from about $10 \%$ to the value above $40 \%$. Later on, the proportion of short-term foreign debt constantly increased and reached above $70 \%$ in 2011 . It can be seen that as for the balance of short-term foreign debt which reflects demands of capital flow, there are great demands of repaying principal and interest for foreign exchange reserves. The results show that since 2003, the actual amount of foreign exchange reserves greatly deviated from theoretical and moderate amount of reserves and it was nearly 2 times more than theoretical and moderate amount of reserves in 2016.

Table 3.Demands of foreign exchange reserves in preventive motivation (II)

\begin{tabular}{c|c|c|c}
\hline Year & $\begin{array}{c}\text { outstanding external } \\
\text { debt (D) }\end{array}$ & $\begin{array}{c}40 \% \text { of outstanding } \\
\text { external debt }\end{array}$ & $\begin{array}{c}\text { Foreign Exchange Reserves } \\
(\mathrm{R})\end{array}$ \\
\hline 2000 & $1,457.30$ & 582.92 of & 1655.74 \\
\hline 2001 & $2,033.00$ & 813.2 & 2121.65 \\
\hline 2002 & $2,026.30$ & 810.52 & 4032.51 \\
\hline 2003 & $2,193.60$ & 877.44 & 6099.32 \\
\hline 2004 & $2,629.90$ & 1051.96 & 8188.72 \\
\hline 2005 & $2,965.40$ & 1186.16 & 10663.44 \\
\hline 2006 & $3,385.90$ & 1354.36 & 15282.49 \\
\hline 2007 & $3,892.20$ & 1556.88 & 19460.3 \\
\hline 2008 & $3,901.60$ & 1560.64 & 23991.52 \\
\hline 2009 & $4,286.50$ & 1714.6 & 28473.38 \\
\hline 2010 & $5,489.40$ & 2195.76 & 31811.48 \\
\hline 2011 & 6950 & 2780 & 33115.89 \\
\hline 2012 & 7369.9 & 2947.96 & 38213.15 \\
\hline 2013 & 8631.7 & 3452.68 & 38430.18 \\
\hline 2014 & 8955.5 & 3582 & 33303.62 \\
\hline 2015 & 7462.8 & 2985.12 & 30105.17 \\
\hline 2016 & 9376 & 3750.56 & \\
\hline
\end{tabular}

Unit: hundred million US dollars

Source of data: Information on: http://www.safe.gov.cn

(II) P. uidotti, the former Finance Minister of Argentina, thought that the foreign exchange reserves of a country shall meet demands to repay foreign debt due within a year, which means the proportion of reserves in balance of external debt reflects a country's ability of paying off foreign debt. The international warning line is $30 \%$ and it is $30 \%$ to $50 \%$ in general. In case one median is determined, the moderate and theoretical amount of reserves can be calculated according to $40 \%$ of the balance of foreign debt from 2000 to 2016 . The results show that the actual amount of reserves greatly deviates from theoretical and moderate amount of reserves. However, it is worth noting that since 2011, the proportion of short-term foreign debt (the term of repayment is one year) was up to the value above $70 \%$ and the customary $40 \%$ was not appropriate. Even though $70 \%$ or even $100 \%$ of the balance of foreign debt is deemed as theoretical amount of reserves, actual foreign exchange reserves are still higher than the moderate level. As of 2016, the actual foreign exchange reserves were 5 times higher than the balance of short-term foreign debt. 
Table 4.Demands of foreign exchange reserves in effectiveness-oriented motivation

\begin{tabular}{c|c|c|c}
\hline Year & GDP & $25 \%$ of GDP & $\begin{array}{c}\text { Foreign Exchange } \\
\text { Reserves (R) }\end{array}$ \\
\hline 2000 & 12113.46 & & 1655.74 \\
\hline 2001 & 13394.12 & 3028.366 & 2121.65 \\
\hline 2002 & 14705.5 & 3348.529 & 2864.07 \\
\hline 2003 & 16602.88 & 3676.374 & 4032.51 \\
\hline 2004 & 19553.47 & 4150.719 & 6099.32 \\
\hline 2005 & 22866.91 & 4888.369 & 8188.72 \\
\hline 2006 & 27526.84 & 5716.729 & 10663.44 \\
\hline 2007 & 35538.18 & 6881.711 & 15282.49 \\
\hline 2008 & 46005.89 & 8884.544 & 23991.52 \\
\hline 2009 & 51102.53 & 11501.47 & 28473.38 \\
\hline 2010 & 61013.41 & 12775.63 & 31811.48 \\
\hline 2011 & 75757.2 & 15253.35 & 33115.89 \\
\hline 2012 & 85602.76 & 18939.3 & 38213.15 \\
\hline 2013 & 96112.58 & 21400.69 & 38430.18 \\
\hline 2014 & 104834 & 24028.14 & 33303.62 \\
\hline 2015 & 110630.7 & 26208.49 & 30105.17 \\
\hline 2016 & 112028.5 & 27657.66 & \\
\hline
\end{tabular}

Unit: hundred million US dollars

Source of data: [1] Information on: http://www. stats.gov.cn, [2] Information on: http:// www. safe. gov.cn

\subsection{Demands of Foreign Exchange Reserves in Effectiveness-Oriented Motivation}

Johnson (1958) thought, the proportion of a country's foreign exchange reserves in GDP can reflect demands of the reserve size for changes in economic development. The moderate size of reserves can be calculated according to $25 \%$ of GDP from 2000 to 2016 . The data show that foreign exchange reserves from 2000 to 2003 in our country were less than the theoretical and moderate size. Since 2004, the amount of foreign exchange reserves in our country started to rapidly increase and the actual amount was higher than the moderate level. In 2010, the proportion between actual amount of foreign exchange reserves and GDP was up to $47 \%$ at the greatest extent. Later on, due to rapid increase of GDP, the proportion decreased but it was still higher than $25 \%$ of moderate level.

To sum up, if measured from aspect of the demand motive at a single level, the theoretical and moderate amount of foreign exchange reserves is much lower than the actual foreign exchange reserves in our country.

\section{Analysis Based on Adequacy Standard of IMF Foreign Exchange Reserves}

After the financial crisis in Asia in 1990s, it can be easily seen from experience and lessons that before capital account of a country was open to the public, moderate and mature financial system is an important precondition. Haruhiko Kuroda, President of Asian Development Bank, pointed out it was necessary to carry out reform for global pattern of foreign exchange reserves dominated by dollars at present so as to adapt to current economic situation better and ensure financial stability in the world. Therefore, in case the moderate size of foreign exchange reserves in a country was measured from aspect of demand motive at a single level, it is insufficient to guarantee a country's international liquidity and ability to withstand shock of external financial crisis.

In 2001, the International Monetary Fund (IMF) pointed out in the document of Guide for Management of International Reserves and emphasized the overall standard that the size of foreign exchange reserves shall be sufficient to keep international debt paying ability, maintain investors' confidence, resist financial crisis, enhance the ability to intervene foreign exchange market, stabilize the balance of international payment and resist external crisis. With further development of economy 
and capital globalization, foreign exchange reserves of a country are faced with double demands, namely internal demands of enterprises and individuals in diversified allocation of assets and external demands of economic exchanges with foreign countries. For this reason, the International Monetary Fund (IMF) (2011) pointed out in the document of Specific Suggestions for Adequacy Assessment of Foreign Exchange Reserves that the weighted measurement method for risk of adequacy of foreign exchange reserves focuses on four core indexes which are respectively short-term foreign debt(D), other liabilities of securities (including medium and long-term debts and equity debt)(SD), domestic current assets (the broad money supply M2 is deemed as its approximate value) and amount of exports(EX). These are four main factors for demands of foreign exchange reserves. The specific formulas are as follows:

Emerging market countries of fixed exchange rate system:

$$
R f=30 \% D+15 \% S D+10 \% M 2+10 \% E X
$$

Emerging market countries of floating exchange rate system:

$$
R m=30 \% D+10 \% S D+5 \% M 2+5 \% E X
$$

At present, our country is a country with managed floating exchange rate system and the coverage range of adequacy of foreign exchange reserves from 2000 to 2016 can be calculated according to adequacy standard of IMF foreign exchange reserves. The results show that compared with actual amount of foreign exchange reserves in our country, the actual size of foreign exchange reserves from 2000 to 2001 in our country was within coverage range of adequacy and it was higher than upper limit of adequacy in other years, which means it was higher than moderate size of foreign exchange reserves. In view that the capital account regulation was gradually slack in our country, IMF (2015) thought in case the capital regulation was slack in a country, the risk of capital outflow would greatly increase and the weight of M2 shall be increased but it is not allowed to exceed $10 \%$. On the basis of this, the adequacy standard can be up to 2.8 trillion yuan. As of the end of 2016, the actual foreign exchange reserves in our country were still higher than this adequacy standard.

Table 5. Adequacy standard of IMF foreign exchange reserves

\begin{tabular}{|c|c|c|c|}
\hline Year & $\begin{array}{c}\text { Lower limit of Adequacy } \\
\text { standard (100\%) }\end{array}$ & $\begin{array}{c}\text { Upper limit of Adequacy } \\
\text { standard (150\%) }\end{array}$ & $\begin{array}{c}\text { Foreign Exchange } \\
\text { Reserves (R) }\end{array}$ \\
\hline 2000 & 1300.435 & 1950.653 & 1655.74 \\
\hline 2001 & 1652.98 & 2479.47 & 2121.65 \\
\hline 2002 & 1877.765 & 2816.648 & 2864.07 \\
\hline 2003 & 2257.795 & 3386.693 & 4032.51 \\
\hline 2004 & 2730.935 & 4096.403 & 6099.32 \\
\hline 2005 & 3287.745 & 4931.618 & 8188.72 \\
\hline 2006 & 3943.215 & 5914.823 & 10663.44 \\
\hline 2007 & 4810.24 & 7215.36 & 15282.49 \\
\hline 2008 & 5776.225 & 8664.338 & 19460.3 \\
\hline 2009 & 6700.06 & 10050.09 & 23991.52 \\
\hline 2010 & 8325.9 & 12488.85 & 28473.38 \\
\hline 2011 & 10284.72 & 15427.07 & 31811.48 \\
\hline 2012 & 11681.62 & 17522.43 & 33115.89 \\
\hline 2013 & 13452.09 & 20178.13 & 38213.15 \\
\hline 2014 & 14926.64 & 22389.95 & 38430.18 \\
\hline 2015 & 15676.3 & 23514.45 & 33303.62 \\
\hline 2016 & 16301.1 & 24451.58 & 30105.17 \\
\hline
\end{tabular}

Unit: hundred million US dollars

Source of data: [1] Information on: http: //www. stats.gov.cn [2] Information on: http: //www. safe.gov.cn 


\section{Conclusions}

It can be seen that existing foreign exchange reserves in our country are still sufficient and in leading position throughout the world. Therefore, on the premise of meeting demand motives at all levels of foreign exchange reserves in our country, it is necessary to further focus on the following aspects: firstly, ensure the size of foreign exchange reserves in our country steadily increases and reach the range of moderate size which meets demands and consider inevitable short-term and moderate fluctuation of reserves from a rational aspect. Secondly, enhance diversified allocation of foreign exchange reserves and then innovate and support the national strategy for construction of "the Belt and Road". Thirdly, maintain financial stability, normalize management of international capital flow, continue to suppress "hot money" and malicious interest arbitrage and prevent the risk of crossborder capital flow. Fourthly, when the exchange rate is nearly marketized, the "bi-directional fluctuation" in which the exchange rate focuses on balance level of RMB is common in the market. Therefore, it is essential to increase the market acceptability of fluctuation range and reasonably guide market expectation.

\section{References}

[1]. Guangyou Zhou. Sumei Luo, Multi-level optimal allocation of foreign exchange reserve assets -based on the analysis framework of transactional demand, Journal of Financial Research, 2014(9):18-33.

[2]. Gulping Hemet al. The optimal scale of international reserves in the process of currency internationalization, Studies of International Finance, 2014(3): 21-31.

[3]. Sumer Luo, et al. The multi-level optimal allocation of monetary foreign exchange reserve assets, The Journal of Quantitative \& Technical Economics, 2013(6): 19-35.

[4]. Young Chen, et.al. Forecasting and Analysis of Foreign Exchange Reserves Based on Multifactor VAR Model, Statistics \& Decision, 2013(13): 148-149.

[5]. Yeti Ma. The Macroeconomic Effect of China's Foreign Exchange Reserve Growth: Based on Time-Variable Parameter State Space Model, Journal of Northeast Normal University (Philosophy and Social Sciences), and 2014(3): 105-111.

[6]. Assessing Reserve Adequacy-Specific Proposals, 2015 (4).

[7]. Information on: http://www.imf.org/external/np/pp/eng/2014/121914.pdf. 